\title{
PERANCANGAN SISTEM MANAJEMEN KINERJA SDM BERBASIS HUMAN RESOURCES SCORECARD DI PT ASIA PENTA GARMENT
}

\author{
Dini Yulianti \\ Jurusan Teknik Industri \\ Universitas Bandung Raya dpm. UICM \\ Email: diniyulianti 17@yahoo.com.
}

\begin{abstract}
Abstrak
Penelitian ini bertujuan untuk merancang sistem manajemen kinerja SDM dengan menggunakan model HR Scorecard. Model ini merupakan rancangan pengelolaan arsitektur SDM sebagai asset strategic dan pengukuran sumber daya manusia pada kinerja bisnis yang menghubungkan antara strategi-orang-kinerja melalui 4 perspektif, yaitu perspektif keuangan, perspektif konsumen, perspektif proses bisnis internal dan perspektif pembelajaran dan pertumbuhan. Rancangan sistem manajemen kinerja berupaya untuk memastikan standard dan sasaran kinerja yang dibuat, dan dilakukan untuk meningkatkan potensi kinerja masa datang. Sistem Manajemen kinerja meliputi 3 proses yaitu proses perencanaan kinerja, proses perbaikan kinerja, dan proses tinjauan/pemeriksaan kinerja. Hasil Rancangan sistem manajemen kinerja SDM berbasis HR Scorecard adalah untuk memaksimalkan keuntungan shareholders dapat diperoleh dari peningkatan nilai rasio total pendapatan terhadap biaya SDM (perspektif keuangan) yang memiliki hubungan dengan peningkatan nilai kinerja pegawai (perspektif konsumen). Peningkatan nilai kinerja pegawai dilatarbelakangi dengan peningkatan persentase jumlah pegawai yang mengikuti pelatihan dan pendidikan terhadap total pegawai (perspektif bisnis internal) yang memiliki hubungan terhadap persentase realisasi man month pelatihan dan pendidikan pegawai (perspektif pembelajaran dan pertumbuhan). Hasil pengukuran kinerja SDM perusahaan secara keseluruhan adalah cukup, dengan nilai 3,531.
\end{abstract}

\begin{abstract}
This research aims to design HR performance management system using the HR scorecard model. This model is a layout to manage HR architecture as a strategic asset and to measure HR on business performance that connects between strategy, people, and performance from four perspectives, namely financial, consumer, internal business process, and learning and growing perspectives. Design of performance management system try to ensure performance's standards and objectives, and is made to improve future potential performance. The resulting scores can be used as evaluation material by the company in order to improve HR performance. The result of designing HR performance management system based on HR Scorecard is to maximize the profits of the shareholders by increasing the ratio between total income and HR cost (financial perspective). Improvements of the employees' performance score is motivated by the increase of the percentage of the employees that attend training and education to the total number of employees (internal business perspective) that has connections to the percentage of the realization of man month training and education of the employees (learning and growing perspective). The result of the HR performance measurement of the company on the whole is adequate, with score of 3.531 .
\end{abstract}

Keywords: performance management, scorecard model, human resources.

\section{PENDAHULUAN}

Kinerja perusahaan dapat tercapai mengacu pada kinerja pegawai yang diukur berdasarkan standar/kriteria yang telah ditetapkan organisasi.pengelolaan untuk mencapai kinerja pegawai yang tinggi terutama dimaksudkan untuk meningkatkan 
kinerja organisasi secara keseluruhan. Pengembangan dan peningkatan potensi sumber daya manusia (SDM) secara berkesinambungan memerlukan sebuah sistem manajemen kinerja.

PT Asia Penta Garment berdiri pada tahun 2005 yang mengkhususkan diri dalam produk-produk rajutan dan tenunan, terutama $T$-shirt, kaos, rok, atasan dan sebagainya. Di Indonesia industri tenun dibagi menjadi dua sektor, sektor mesin modern dan sektor tenun tangan konvensional. PT. Asia Penta Garment didukung oleh 85 tenaga profesional dan 600 orang karyawan. Sistem Manajemen Kinerja SDM di PT. Asia Penta Garment masih bersifat tradisional yang hanya mengandalkan laporan finansial.

Sistem Manajemen Kinerja merupakan salah satu hal yang penting bagi pencapaian tujuan, visi, misi organisasi karena merupakan aktivitas untuk mengetahui sampai seberapa jauh suatu tujuan dicapai, menilai prestasi organisasi, pimpinan, unit kerja, dan individu organisasi, serta untuk memprediksi harapan-harapan organisasi di masa datang.

Sistem manajemen kinerja SDM di PT. Asia Penta Garmen masih difokuskan pada kinerja individu (pegawai). Penilaian kinerja dilakukan oleh pimpinan divisi dimana pegawai ditempatkan, penilaian dilakukan dengan melihat kinerja dari pegawai yang bersangkutan.

Tabel 1. Persentase Turn over karyawan di PT. Asia Penta Garmen

\begin{tabular}{|c|c|}
\hline Tahun & $\begin{array}{c}\text { Persentase Turn over } \\
\text { karyawan }\end{array}$ \\
\hline 2012 & $25 \%$ \\
\hline 2013 & $40 \%$ \\
\hline 2014 & $30 \%$ \\
\hline
\end{tabular}

Pada tabel di atas menjelaskan turn over karyawan di PT. Asia Penta Garment selama 3 tahun. Turn over karyawan perusahaan cukup tinggi yaitu sekitar 15-20 orang karyawan per bulannya. Dikarenakan tidak adanya sistem insentif dan bonus untuk karyawan, sehingga karyawan kurang puas dan mengakibatkan turn over karyawan yang cukup tinggi. Di perusahaan ini juga belum terbentuk sistem manajemen kinerja SDM.

Maka dari itu penulis bertujuan untuk merancang sistem manajemen kinerja SDM berbasis Human Resources Scorecard (HR Scorecard) di PT. Asia Penta Garment. Diharapkan perusahaan dapat mempunyai perancangan sistem manajemen kinerja SDM dan dapat memaksimalkan keuntungan bagi perusahaan.

Model ini merupakan perancangan pengelolaan arsitektur SDM sebagai asset strategic dan pengukuran kontribusi sumber daya manusia pada kinerja bisnis yang menghubungkan antara strategi - orang - kinerja melalui empat perspektif, yaitu perspetif keuangan, perspektif pelanggan/konsumen, perspektif proses bisnis internal, serta perspektif pembelajaran dan pertumbuhan (Dharma \& Sunatrio, 2001).

Diupayakan rancangan sistem manajemen kinerja ini dapat memastikan standar kinerja yang dibuat, dan dilakukan untuk meningkatkan potensi kinerja di masa datang. Sistem Manajemen Kinerja meliputi 3 proses yaitu proses perencanaan kinerja, proses perbaikan kinerja, proses tinjauan/pemeriksaan kinerja. Ketiga proses ini akan dirumuskan dalam tahapan model HR Scorecard.

Proses perencanaan kinerja merupakan tahap mengidentifikasi strategi bisnis, membangun kasus bisnis untuk SDM sebagai modal strategik, menciptakan peta strategi, mengidentifikasi HR Deliverable dalam peta strategi, serta kemitraan antara arsitektur 
SDM dan HR Deliverable. Proses perbaikan kinerja merupakan proses merancang rancangan $H R$ Scorecard.

Rancangan ini akan memperlihatkan ukuran-ukuran dimensi HR Scorecard. Proses tinjauan pemeriksaan kinerja merupakan pelaksanaan manajemen pengukuran, yaitu dengan dilakukan perhitungan nilai dimensi rancangan $H R$ Scorecard. Nilai yang diperoleh dapat dijadikan bahan evaluasi bagi perusahaan dalam upaya peningkatan kinerja SDM.

\section{Identifikasi Masalah}

Saat ini pegawai sebagai sumber daya manusia sebagai aset yang paling penting tetapi paling sulit untuk dipahami dan diukur, sehingga sulit untuk dikelola, hal ini dikarenakan SDM menyangkut sejumlah orang dengan karakteristik masing-masing. Selain itu, para profesi di bidang SDM selalu dihadapi tantangan baik yang datang dari faktor eksternal maupun internal organisasi sehingga diperlukan perspektif yang strategik sesuai peranannya dalam organisasi.

Salah satu cara yang dianggap tepat untuk ini adalah melalui HR Scorecard menawarkan rancangan pengelolaan arsitektur sumber daya manusia sebagai aset strategik, dan sistem pengukuran kontribusi sumber daya manusia pada kinerja perusahaan.

Berdasarkan hal tersebut maka perumusan masalahnya adalah sebagai berikut:

- Bagaimana manajemen kinerja SDM yang ada di PT. Asia Penta Garment?

- Bagaimana mengidentifikasi kelemahan manajemen kinerja SDM yang sedang berjalan di PT. Asia Penta Garment?

- Bagaimana menentukan variabel dan indikator untuk membuat perancangan sistem manajemen kinerja?

- Bagaimana Merancang suatu sistem Manajemen Kinerja SDM berbasis $H R$ Scorecard di PT. Asia Penta Garmen?

\section{Tujuan Penelitian}

Untuk lebih jelasnya dan berdasarkan dari perumusan masalah sebelumnya, maka tujuan penelitian ini adalah sebagai berikut:

a. Mengkaji manajemen kinerja SDM yang sedang berjalan di PT. Asia Penta Garment.

b. Mengidentifikasi faktor-faktor kelemahan manajemen kinerja SDM yang sedang berjalan di PT. Asia Penta Garment.

c. Menentukan variabel dan indikator perancangan sistem manajemen kinerja SDM.

d. Untuk dapat mengetahui suatu perancangan Sistem Manajemen Kinerja SDM berbasis HR Scorecard untuk PT. Asia Penta Garment."

\section{METODE PENELITIAN}

PERUMUSAN MASALAH 


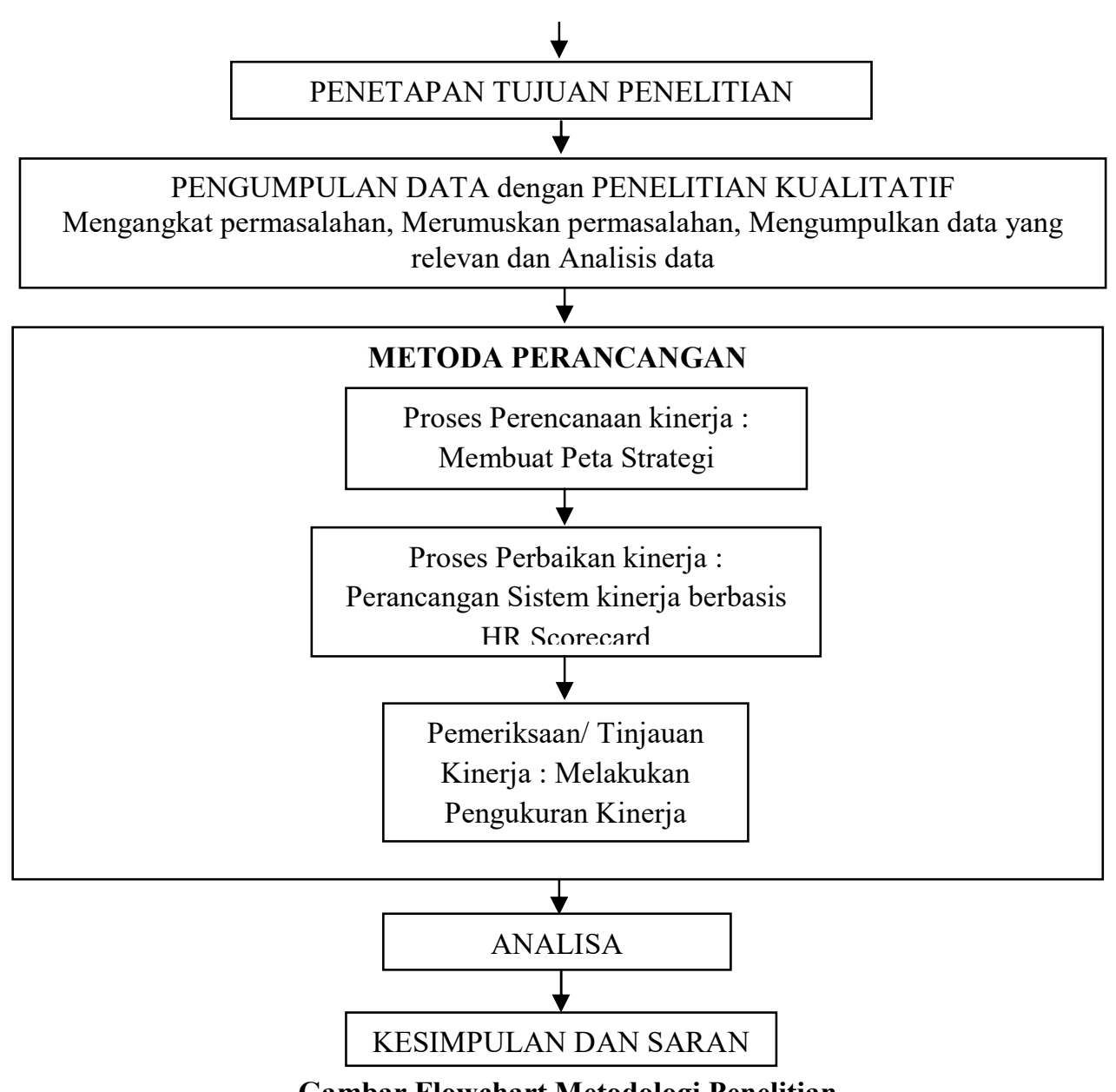

Gambar Flowchart Metodologi Penelitian

\section{Model Pemecahan Masalah \\ Performance Management}

Definisi menurut Michael Amstrong (2009:9) : Performance management is a systematic process for improving organizational performance by developing the performance of individual and teams. It is a means of getting better result by understanding and managing performance within an agreed framework of planned goals, standards and competency requirements. Manajemen kinerja SDM terdapat tiga proses utama/penting, yaitu:

- Perencanaan kinerja (performance plan), merupakan tahap untuk merencanakan prioritas kinerja pegawai yang akan diukur. Pada tahap ini akan diidentifikasikan visi, misi, dan strategi dalam pencapaian visi perusahaan tersebut.

- Perbaikan kinerja (performance improvement), yaitu merancang kembali pengukuran kinerja pegawai sebagai upaya perbaikan secara berkesinambungan.

- Peninjauan/pemeriksaan kinerja (performance review), yaitu selain dilakukan pengukuran kinerja pegawai, juga dilakukan evaluasi terhadap pencapaian nilai kinerja pegawai.

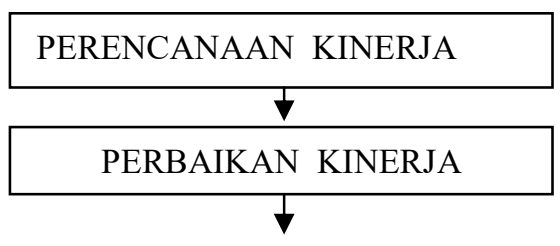




\section{PEMERIKSAAN KINERJA \\ Gambar Proses Manajemen Kinerja}

\section{Human Resource Scorecard}

Human Resource Scorecardmerupakan metode pengukuran kinerja sumber daya manusia yang merupakan hasil dari pengembangan metode Balanced Scorecard (Bekker.et.ct, 2001). Pengukuran kinerja SDM dengan HR Scorecard memiliki prinsip yang sama dengan metode Balanced Scorecard, namun perbedaannya terletak pada objek yang diukur. Metode Balanced Scorecard mengukur kinerja perusahaan secara keseluruhan, sedangkan HR Scorecard mengukur kinerja dan kontribusi SDM di dalam suatu perusahaan.

$H R$ Scorecard merupakan sebuah bentuk pengukuran SDM yang mencoba untuk memperjelas peran SDM yang selama ini dianggap intagible untuk diukur perannya terhadap pencapaian visi, misi, dan strategi perusahaan (Pfeeffer, dkk, 2004). HR Scorecard merupakan suatu metode baru dalam pengukuran kinerja SDM dalam upaya meningkatkan kinerja organisasi (Mangkunegara, Anwar Prabu, 2005)

\section{Langkah-langkah Pelaksanaan HR Scorecard}

Proses implementasi HR Scorecard disajikan dalam 7 langkah proses transformasi arsitektur SDM ke dalam model strategik, seperti terlihat dalam gambar sebagai berikut:

\begin{tabular}{|c|c|}
\hline 1 & Clearly Define Business Strategy \\
\hline 2 & Build A Business Case for HR as A Strategic Asset \\
\hline 3 & $\begin{array}{c}\text { Create Strategy Map Leading and Lagging Indicators Result - } \\
\text { Tangibles and Intangibles }\end{array}$ \\
\hline 4 & Identify HR Deliverables Within The Strategy Map \\
\hline 5 & $\begin{array}{c}\text { Align The HR Architecture with HR Deliverables } \\
\text { Periodically test HR } \\
\text { firm's strategy map } \\
\text { and adjust as } \\
\text { required }\end{array}$ \\
\hline 6 & HR Function $\rightarrow$ HR System $\rightarrow$ Strategic Employee Behaviors \\
\hline 7 & Design The Strategic Measurement System \\
\hline
\end{tabular}

Gambar Transforming The HR Architecture into A Strategic Asset

Sumber: Brian E Bekker, Mark Huselid, and Dave Ulrich, “The HR Scorecard-Lingking People,

Strategy, and Performance”, Harvard Business Scholl Press, Boston MA, 2001. 


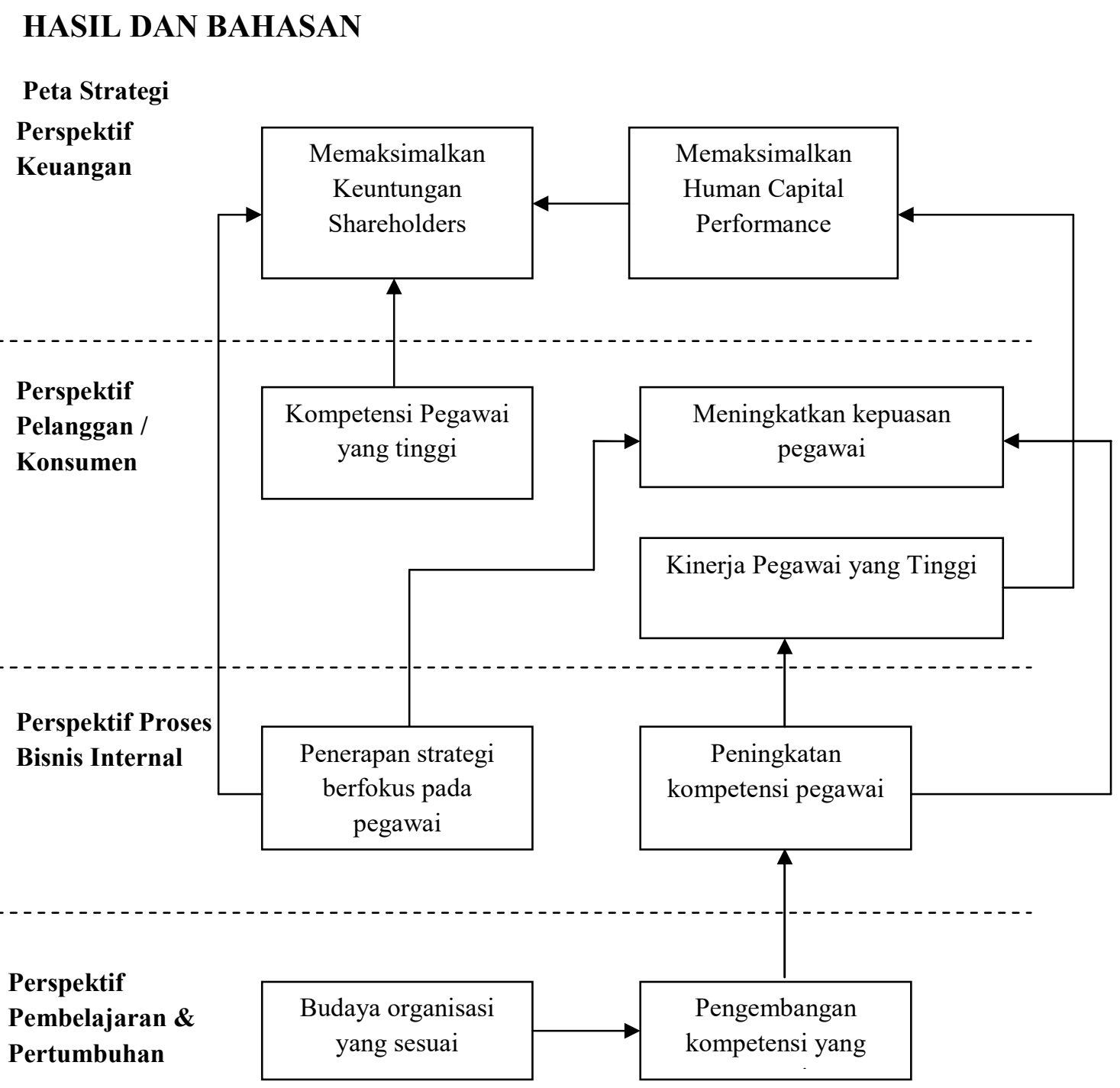

Gambar Peta Strategi

\section{Identifikasi Indikator Penyebab (Leading Indicator) dan Indikator Akibat (Lagging Indicator)}

Tabel 1. IdentifikasiLeading Indicator dan Lagging Indicator

\begin{tabular}{|c|c|c|c|}
\hline Perspektif & Sasaran Strategis & Indikator Penyebab & Indikator Akibat \\
\hline \multirow{4}{*}{ Keuangan } & $\begin{array}{c}\text { Memaksimalkan } \\
\text { keuntungan Shareholder }\end{array}$ & Human Capital Value Added & $\begin{array}{c}\text { Rasio Total Pendapatan } \\
\text { Terhadap Biaya SDM }\end{array}$ \\
\cline { 2 - 4 } & $\begin{array}{c}\text { Memaksimalkan Human } \\
\text { Capital Performance }\end{array}$ & $\begin{array}{c}\text { Persentase Pengeluaran SDM } \\
\text { Terhadap Pendapatan }\end{array}$ & Biaya SDM per Pegawai \\
\cline { 2 - 4 } $\begin{array}{c}\text { Pelanggan/ } \\
\text { Konsumen }\end{array}$ & $\begin{array}{c}\text { Meningkatkan Kepuasan } \\
\text { Pegawai }\end{array}$ & Turn over pegawai & Indeks kepuasan pegawai \\
\cline { 2 - 4 } & $\begin{array}{c}\text { Kompetensi Pegawai yang } \\
\text { tinggi }\end{array}$ & Nilai Kompetensi pegawai & $\begin{array}{c}\text { Rata - rata Nilai Kompetensi } \\
\text { Pegawai }\end{array}$ \\
\cline { 2 - 4 } & $\begin{array}{c}\text { Kinerja Pegawai yang } \\
\text { Tinggi }\end{array}$ & Nilai Kinerja Pegawai & $\begin{array}{c}\text { Rata - rata nilai kinerja } \\
\text { pegawai }\end{array}$ \\
\hline
\end{tabular}


Yuliati, Dini. 2019. Perancangan Sistem Manajemen Kinerja SDM Berbasis

Human Resources Score Card di PT Asia Penta Garment. Sainteks, 1(1): 1-16.

\begin{tabular}{|c|c|c|c|}
\hline \multirow[t]{3}{*}{$\begin{array}{l}\text { Proses Bisnis } \\
\text { Internal }\end{array}$} & $\begin{array}{c}\text { Menerapkan strategi } \\
\text { berfokus pada pegawai }\end{array}$ & $\begin{array}{c}\text { Persentase keikutsertaan } \\
\text { pegawai dalam pencapaian } \\
\text { tujuan }\end{array}$ & $\begin{array}{l}\text { Persentase realisasi biaya } \\
\text { kompensasi per pegawai } \\
\text { terhadap skema rencana } \\
\text { strategis }\end{array}$ \\
\hline & \multirow[t]{2}{*}{$\begin{array}{c}\text { Meningkatkan Kompetensi } \\
\text { Pegawai }\end{array}$} & $\begin{array}{c}\text { Biaya program pelatihan dan } \\
\text { pendidikan per pegawai }\end{array}$ & Jam Pelatihan/orang/tahun \\
\hline & & $\begin{array}{c}\text { Persentase waktu pelatihan } \\
\text { terhadap total waktu kerja yang } \\
\text { tersedia }\end{array}$ & $\begin{array}{c}\text { Persentase Jumlah Pegawai } \\
\text { yang mengikuti Pelatihan dan } \\
\text { Pendidikan Terhadap Total } \\
\text { Pegawai }\end{array}$ \\
\hline \multirow{2}{*}{$\begin{array}{l}\text { Pembelajaran } \\
\text { dan } \\
\text { Pertumbuhan }\end{array}$} & $\begin{array}{c}\text { Budaya Organisasi yang } \\
\text { sesuai }\end{array}$ & $\begin{array}{c}\text { Penerapan Budaya Perusahaan } \\
\text { yang sesuai }\end{array}$ & $\begin{array}{c}\text { Tingkat Pemahaman terhadap } \\
\text { Budaya perusahaan }\end{array}$ \\
\hline & $\begin{array}{c}\text { Pengembangan kompetensi } \\
\text { yang sesuai }\end{array}$ & $\begin{array}{l}\text { Jumlah program pelatihan dan } \\
\text { pendidikan pegawai per tahun }\end{array}$ & $\begin{array}{l}\text { Persentase realisasi man } \\
\text { month pelatihan dan } \\
\text { pendidikan pegawai }\end{array}$ \\
\hline
\end{tabular}

Tabel 2. Formulasi Perhitungan Tolok Ukur Penyebab dan Akibat HR Scorecard.

\begin{tabular}{|c|c|c|}
\hline Perspektif & Tolok Ukur Strategis & Formulasi Perhitungan \\
\hline \multirow{5}{*}{ Keuangan } & Human Capital Value Added & $\begin{array}{l}\text { (Pendapatan Organisasi - HPP - Biaya Kompensasi) / Jumlah } \\
\text { Pegawai } \\
\text { Sumber : Ruky. S. Ahmad., "SDM Berkualitas, Mengubah Visi } \\
\text { menjadi Realitas", PT Gramedia, } 3003\end{array}$ \\
\hline & $\begin{array}{l}\text { Persentase Pengeluaran SDM } \\
\text { Terhadap Pendapatan }\end{array}$ & $\begin{array}{l}\frac{\text { TatalBiayaPendapatan }}{\text { JumlahPegawai }} \times 100 \% \\
\text { Sumber : Becker,E,Brian, Huselid,A, Mark, Ulrich Dave, "HR } \\
\text { Scorecard : Lingking People, Strategy, and Performance”, } \\
\text { Harvard Business School, 2001. }\end{array}$ \\
\hline & $\begin{array}{l}\text { Rasio Total Pendapatan } \\
\text { Terhadap Biaya SDM }\end{array}$ & $\begin{array}{c}\text { (Total Pendapatan / Total Biaya SDM) x 100\% } \\
\text { Sumber : Summanth, J, David, Productivity Engineering and } \\
\text { Management, Prence Hill, } 1964\end{array}$ \\
\hline & Biaya SDM per Pegawai & $\begin{array}{c}\text { (Total Biaya SDM / Total Pegawai) x } 100 \% \\
\text { Sumber : Becker,E,Brian, Huselid,A, Mark, Ulrich Dave, “HR } \\
\text { Scorecard : Lingking People, Strategy, and Performance”, } \\
\text { Harvard Business School, } 2001 .\end{array}$ \\
\hline & HR ROI Indeks & $\begin{array}{l}\text { (Pendapatan Organisasi - HPP - Biaya Kompensasi) / Jumlah } \\
\text { Pegawai } \\
\text { Sumber : Ruky,S,Ahmad, SDM Berkualitas,Mengubah Visi } \\
\quad \text { Menjadi Realitas”, PT. Gramedia., } 2003\end{array}$ \\
\hline \multirow[t]{6}{*}{$\begin{array}{l}\text { Konsumen / } \\
\text { Pelanggan }\end{array}$} & Tingkat Turn Over Pegawai & $\begin{array}{l}\text { (Jumlah Pegawai yang masuk dan keluar / Total Pegawai) } \mathrm{x} \\
100 \%\end{array}$ \\
\hline & Indeks Kepuasan Pegawai & Kuesioner Kepuasan Pegawai \\
\hline & Nilai Kompetensi Pegawai & Laporan Management Performance Appraisal \\
\hline & Nilai Kinerja Pegawai & Laporan Management Performance Appraisal \\
\hline & $\begin{array}{l}\text { Rata - rata nilai kompetensi } \\
\text { pegawai }\end{array}$ & Data Perusahaan \\
\hline & $\begin{array}{l}\text { Rata - rata nilai kinerja } \\
\text { karyawan }\end{array}$ & Data Perusahaan \\
\hline
\end{tabular}

\begin{tabular}{|c|c|l|}
\hline $\begin{array}{c}\text { Proses Bisnis } \\
\text { Internal }\end{array}$ & $\begin{array}{c}\text { Persentase keikutsertaan } \\
\text { pegawai dalam pencapaian }\end{array}$ & $\begin{array}{l}\text { (Jumlah Keikutsertaan Pegawai / Total pegawai) x 100\% } \\
\text { Sumber : Becker,E,Brian, Huselid,A, Mark, Ulrich Dave, }\end{array}$ \\
\hline
\end{tabular}


Yuliati, Dini. 2019. Perancangan Sistem Manajemen Kinerja SDM Berbasis

Human Resources Score Card di PT Asia Penta Garment. Sainteks, 1(1): 1-16.

\begin{tabular}{|c|c|c|}
\hline & tujuan & $\begin{array}{l}\text { "HR Scorecard: Lingking People, Strategy, and } \\
\text { Performance", Harvard Business School, } 2001 .\end{array}$ \\
\hline & $\begin{array}{l}\text { Biaya program pelatihan dan } \\
\text { pendidikan per pegawai }\end{array}$ & $\begin{array}{l}\text { (Biaya program pelatihan dan pendidikan pegawai / Total } \\
\text { pegawai) x } 100 \% \\
\text { Sumber : Becker,E,Brian, Huselid,A, Mark, Ulrich Dave, } \\
\text { "HR Scorecard: Lingking People, Strategy, and } \\
\text { Performance", Harvard Business School, 2001. }\end{array}$ \\
\hline & $\begin{array}{l}\text { Persentase waktu pelatihan } \\
\text { terhadap total waktu kerja } \\
\text { yang tersedia }\end{array}$ & $\begin{array}{c}\text { (Total waktu pelatihan / Total waktu kerja yang tersedia) x } \\
100 \% \\
\text { Sumber : Laporan PT. Asia Penta Garmen }\end{array}$ \\
\hline & $\begin{array}{l}\text { Persentase realisasi biaya } \\
\text { kompensasi per pegawai } \\
\text { terhadap skema rencana } \\
\text { strategis }\end{array}$ & $\begin{array}{c}\text { (Biaya Kompensasi per pegawai yang dikeluarkan / } \\
\text { Rencana biaya kompensasi per pegawai) x 100\% } \\
\text { Sumber : Becker,E,Brian, Huselid,A, Mark, Ulrich Dave, } \\
\text { "HR Scorecard: Lingking People, Strategy, and } \\
\text { Performance”, Harvard Business School, } 2001 .\end{array}$ \\
\hline & Jam Pelatihan/orang/tahun & $\begin{array}{l}\text { (Jam pelatihan per tahun / Total Pegawai) x 100\% } \\
\text { Sumber : Becker,E,Brian, Huselid,A, Mark, Ulrich Dave, } \\
\text { "HR Scorecard: Lingking People, Strategy, and } \\
\text { Performance", Harvard Business School, } 2001 .\end{array}$ \\
\hline & $\begin{array}{c}\text { Persentase Jumlah Pegawai } \\
\text { yang mengikuti Pelatihan dan } \\
\text { Pendidikan Terhadap Total } \\
\text { Pegawai }\end{array}$ & $\begin{array}{c}\text { (Jumlah Pegawai yang ikut Pelatihan dan Pendidikan Per } \\
\text { Tahun / Total Pegawai) x 100\% } \\
\text { Sumber : Becker,E,Brian, Huselid,A, Mark, Ulrich Dave, } \\
\text { "HR Scorecard: Lingking People, Strategy, and } \\
\text { Performance", Harvard Business School, 2001. }\end{array}$ \\
\hline $\begin{array}{l}\text { Pembelajaran dan } \\
\text { Pertumbuhan }\end{array}$ & $\begin{array}{c}\text { Penerapan Budaya } \\
\text { Perusahaan yang sesuai }\end{array}$ & Data Perusahaan \\
\hline & $\begin{array}{c}\text { Tingkat Pemahaman terhadap } \\
\text { Budaya perusahaan }\end{array}$ & Kuesioner Pemahaman Budaya Perusahaan \\
\hline & $\begin{array}{l}\text { Jumlah program pelatihan } \\
\text { dan pendidikan pegawai per } \\
\text { tahun }\end{array}$ & $\begin{array}{c}\text { Jumlah program pelatihan dan pendidikan pegawai per } \\
\text { tahun } \\
\text { Sumber : Data Perusahaan }\end{array}$ \\
\hline & $\begin{array}{l}\text { Persentase realisasi man } \\
\text { month pelatihan dan } \\
\text { pendidikan pegawai }\end{array}$ & $\begin{array}{c}\text { [(Jam Pelatihan x jumlah pegawai pelatihan terealisasi) / } \\
\text { (Jam pelatihan x jumlah pegawai ikut pelatihan rencana) x } \\
100 \%] \\
\text { Sumber : Becker,E,Brian, Huselid,A, Mark, Ulrich Dave, } \\
\text { "HR Scorecard : Lingking People, Strategy, and } \\
\text { Performance", Harvard Business School, 2001. }\end{array}$ \\
\hline
\end{tabular}

\section{Perancangan Sistem Manajemen Kinerja}

Setelah dilakukan proses identifikasi Leading indicator dan lagging indicator, dan proses identifikasi HR Deliverable, maka dapat digambarkan proses penciptaan nilai SDM yang terjadi atau hubungan sebab akibat antar tolok ukur. Hubungan sebab akibat antar indikator pada setiap perspektif dapat dilihat pada gambar 7 .

Hubungan sebab akibat pada perspektif keuangan menunjukkan bahwa apabila terjadi kenaikan persentase biaya SDM terhadap pendapatan, maka nilai HR ROI cenderung akan menurun. Hal ini disebabkan karena nilai HR ROI berkaitan dengan pengembalian investasi SDM yang dikurangi oleh biaya kompensasi pegawainya.Sedangkan biaya kompensasi tersebut merupakan biaya SDM.Hubungan sebab akibat pada perspektif konsumen menunjukkan bahwa rata-rata nilai kompetensi pegawai mempengaruhi nilai kompetensi pegawai sehingga dapat mempengaruhi nilai kinerja pegawai.Nilai kinerja pegawai dapat dipengaruhi oleh nilai kompetensi pegawai, nilai rata-rata kinerja pegawai dan indeks kepuasan pegawai. Indeks kepuasan pegawai 
juga mempengaruhi tingkat turn over karyawan. (jika indeks kepuasan karyawan rendah maka keinginan karyawan untuk keluar semakin besar).

Setelah dilakukan penggambaran hubungan sebab akibat antar indikator pada setiap perspektif, selanjutnya dilakukan penggambaran hubungan sebab akibat antar indikator dari satu perspektif ke perspektif yang lain.
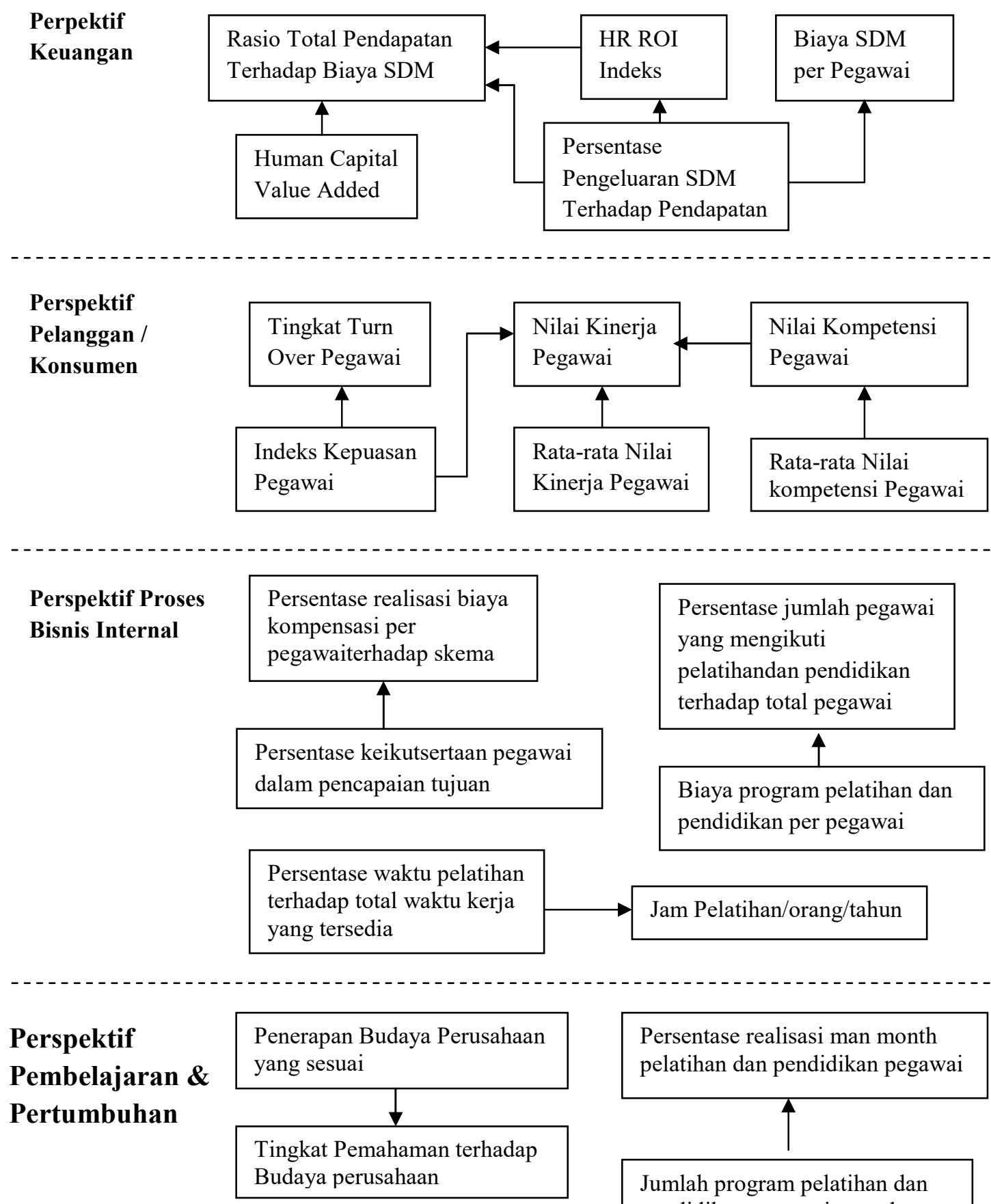

Persentase realisasi man month pelatihan dan pendidikan pegawai

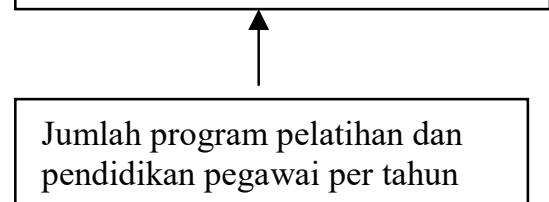

Gambar Hubungan sebab akibat Antar Tolok Ukur Pada Setiap Perspektif 
Yuliati, Dini. 2019. Perancangan Sistem Manajemen Kinerja SDM Berbasis

Human Resources Score Card di PT Asia Penta Garment. Sainteks, 1(1): 1-16.

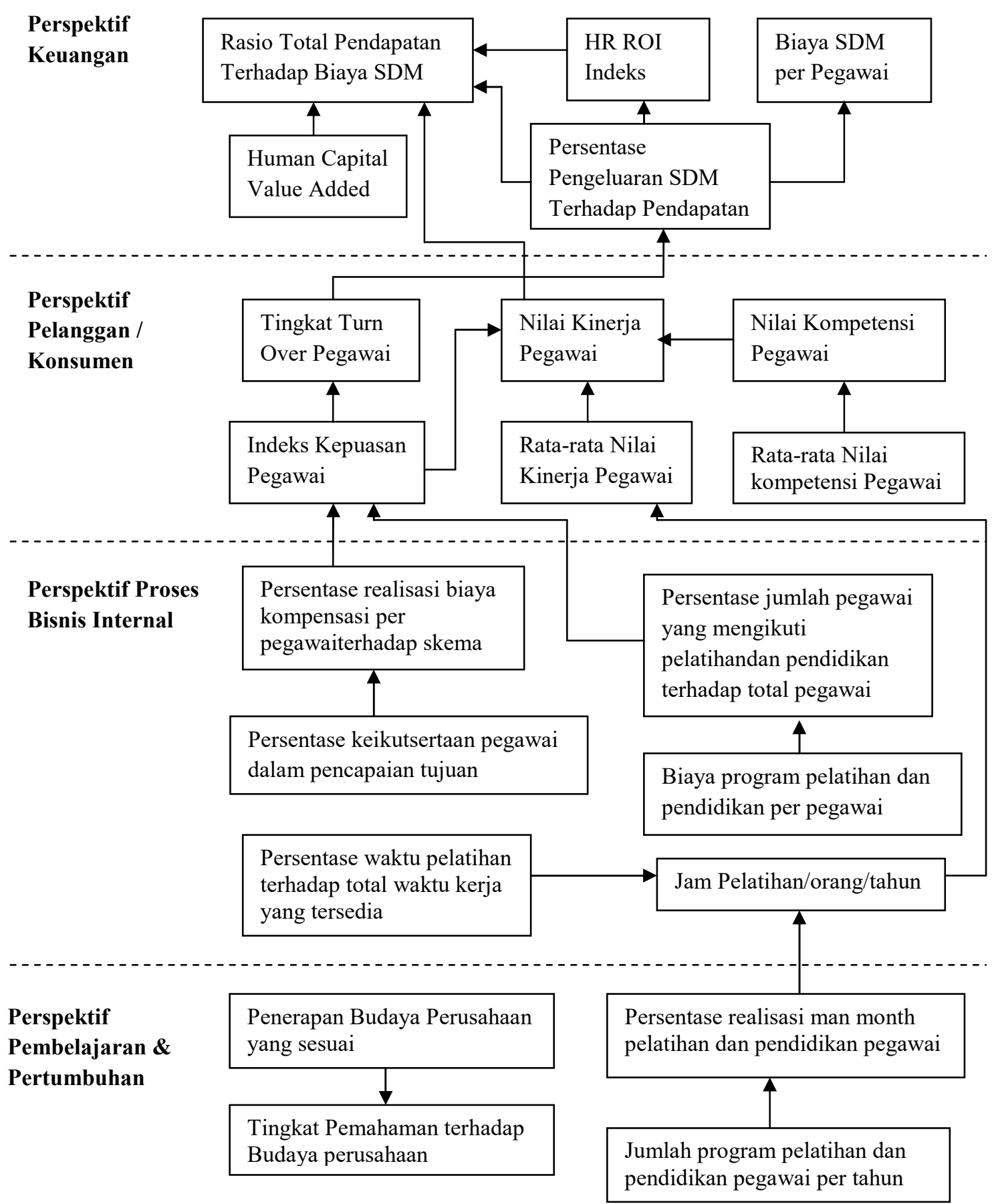

Gambar Hubungan sebab akibat Antar Tolok Ukur Antara Setiap Perspektif

Tabel 3. Rekapitulasi Target dan Pencapaian Tolok ukur pada setiap Perspektif 
Yuliati, Dini. 2019. Perancangan Sistem Manajemen Kinerja SDM Berbasis

Human Resources Score Card di PT Asia Penta Garment. Sainteks, 1(1): 1-16.

\begin{tabular}{|c|c|c|c|c|}
\hline No & Tolok Ukur & Target & Pencapaian & Skor \\
\hline \multicolumn{5}{|c|}{ Perspektif Keuangan } \\
\hline 1 & Human Capital Value Added & 1,5 Milyar & 1,7 milyar & 5 \\
\hline 2 & $\begin{array}{l}\text { Persentase Pengeluaran SDM Terhadap } \\
\text { Pendapatan }\end{array}$ & $2,96 \%$ & $2,50 \%$ & 1 \\
\hline 3 & $\begin{array}{l}\text { Rasio Total Pendapatan Terhadap Biaya } \\
\text { SDM }\end{array}$ & $26,57 \%$ & $26 \%$ & 4 \\
\hline 4 & Biaya SDM per Pegawai & 30 juta & 29 juta & 4 \\
\hline 5 & HR ROI Indeks & 2,45 & 2,40 & 4 \\
\hline \multicolumn{5}{|c|}{ Perspektif Pelanggan / Konsumen } \\
\hline 1 & Tingkat Turn Over Pegawai & $20 \%$ & $40 \%$ & 1 \\
\hline 2 & Indeks Kepuasan Pegawai & $90 \%$ & $62 \%$ & 3 \\
\hline 3 & Nilai Kompetensi Pegawai & 90 & 78 & 4 \\
\hline 4 & Rata-rata Nilai Kompetensi Pegawai & 90 & 78 & 4 \\
\hline 5 & Nilai Kinerja Pegawai & 90 & 76 & 4 \\
\hline 6 & Rata-rata nilai Kinerja Pegawai & 90 & 76 & 4 \\
\hline \multicolumn{5}{|c|}{ Perspektif Proses Bisnis Internal } \\
\hline 1 & $\begin{array}{l}\text { Persentase keikutsertaan pegawai dalam } \\
\text { pencapaian tujuan }\end{array}$ & $100 \%$ & $60,26 \%$ & 2 \\
\hline 2 & $\begin{array}{l}\text { Persentase realisasi biaya kompensasi per } \\
\text { pegawai terhadap skema rencana strategis }\end{array}$ & $100 \%$ & $77 \%$ & 3 \\
\hline 3 & $\begin{array}{l}\text { Persentase jumlah pegawai yang mengikuti } \\
\text { pelatihan dan pendidikan terhadap total } \\
\text { pegawai }\end{array}$ & $80 \%$ & $32,69 \%$ & 3 \\
\hline 4 & $\begin{array}{l}\text { Biaya program pelatihan dan pendidikan per } \\
\text { pegawai }\end{array}$ & Rp $100 \mathrm{jt}$ & Rp 120jt & 2 \\
\hline 5 & Jam Pelatihan/orang/tahun & $\begin{array}{c}60,90 \\
\mathrm{jam} / \text { pegawai/thn }\end{array}$ & $\begin{array}{c}59,70 \\
\text { jam/pegawai/tahu } \\
n\end{array}$ & 5 \\
\hline 6 & $\begin{array}{l}\text { Persentase waktu pelatihan terhadap total } \\
\text { waktu kerja yang tersedia }\end{array}$ & $29,50 \%$ & $27,14 \%$ & 4 \\
\hline \multicolumn{5}{|c|}{ Perspektif Pertumbuhan dan Pembelajaran } \\
\hline 1 & Penerapan Budaya Perusahaan yang sesuai & $80 \%$ & $85,83 \%$ & 5 \\
\hline 2 & $\begin{array}{l}\text { Tingkat Pemahaman terhadap Budaya } \\
\text { perusahaan }\end{array}$ & $80 \%$ & $85,83 \%$ & 5 \\
\hline 3 & $\begin{array}{l}\text { Jumlah program pelatihan dan pendidikan } \\
\text { pegawai per tahun }\end{array}$ & 3 kali & 2 kali & 4 \\
\hline 4 & $\begin{array}{l}\text { Persentase realisasi man month pelatihan } \\
\text { dan pendidikan pegawai }\end{array}$ & $100 \%$ & $98 \%$ & 4 \\
\hline
\end{tabular}

\section{Pengukuran Kinerja Setiap Perspektif}

Pengukuran kinerja setiap perspektif dapat dilakukan dengan menghitung nilai tolok ukur setiap perspektif, dengan cara mengalikan bobot tolok ukur dengan skor tolok ukur. Setelah itu nilai keseluruhan tolok ukur dijumlahkan. Hasil penjumlahan dari semua tolok ukur tersebut yang menjadi nilai kinerja perspektif. 
Yuliati, Dini. 2019. Perancangan Sistem Manajemen Kinerja SDM Berbasis

Human Resources Score Card di PT Asia Penta Garment. Sainteks, 1(1): 1-16.

Tabel 4. Rekapitullasi Pengukuran Kinerja Tolok Ukur dan Perspektif HR Scorecard

\begin{tabular}{|c|c|c|c|c|c|c|}
\hline No & Perspektif & Tolok Ukur & $\begin{array}{l}\text { Bobot } \\
\text { Tolok } \\
\text { Ukur } \\
\end{array}$ & Skor & $\begin{array}{l}\text { Nilai } \\
\text { Tolok } \\
\text { Ukur }\end{array}$ & $\begin{array}{c}\text { Nilai } \\
\text { Perspektif }\end{array}$ \\
\hline \multirow[t]{5}{*}{1} & \multirow[t]{5}{*}{ Keuangan } & Human Capital Value Added & 0,316 & 5 & 1,580 & \multirow[t]{5}{*}{3,683} \\
\hline & & $\begin{array}{l}\text { Persentase Pengeluaran SDM Terhadap } \\
\text { Pendapatan }\end{array}$ & 0,211 & 1 & 0,211 & \\
\hline & & $\begin{array}{l}\text { Rasio Total Pendapatan Terhadap Biaya } \\
\text { SDM }\end{array}$ & 0,16 & 4 & 0,640 & \\
\hline & & Biaya SDM per Pegawai & 0,189 & 4 & 0,756 & \\
\hline & & HR ROI Indeks & 0,124 & 4 & 0,496 & \\
\hline \multirow[t]{6}{*}{2} & \multirow[t]{6}{*}{ Konsumen } & Tingkat Turn Over Pegawai & 0,284 & 1 & 0,284 & \multirow[t]{6}{*}{2,993} \\
\hline & & Indeks Kepuasan Pegawai & 0,155 & 3 & 0,465 & \\
\hline & & Nilai Kompetensi Pegawai & 0,211 & 4 & 0,844 & \\
\hline & & Rata-rata Nilai Kompetensi Pegawai & 0,13 & 4 & 0,52 & \\
\hline & & Nilai Kinerja Pegawai & 0,145 & 4 & 0,58 & \\
\hline & & Rata-rata nilai Kinerja Pegawai & 0,075 & 4 & 0,3 & \\
\hline \multirow[t]{6}{*}{3} & \multirow[t]{6}{*}{$\begin{array}{l}\text { Proses Bisnis } \\
\text { Internal }\end{array}$} & $\begin{array}{l}\text { Persentase keikutsertaan pegawai dalam } \\
\text { pencapaian tujuan }\end{array}$ & 0,098 & 2 & 0,196 & \multirow[t]{6}{*}{3,337} \\
\hline & & $\begin{array}{l}\text { Persentase realisasi biaya kompensasi } \\
\text { per pegawai terhadap skema rencana } \\
\text { strategis }\end{array}$ & 0,291 & 3 & 0,873 & \\
\hline & & $\begin{array}{l}\text { Biaya program pelatihan dan pendidikan } \\
\text { per pegawai }\end{array}$ & 0,067 & 2 & 0,134 & \\
\hline & & Jam Pelatihan/orang/tahun & 0,175 & 5 & 0,875 & \\
\hline & & $\begin{array}{l}\text { Persentase jumlah pegawai yang } \\
\text { mengikuti pelatihan dan pendidikan } \\
\text { terhadap total pegawai }\end{array}$ & 0,217 & 3 & 0,651 & \\
\hline & & $\begin{array}{l}\text { Persentase waktu pelatihan terhadap } \\
\text { total waktu kerja yang tersedia }\end{array}$ & 0,152 & 4 & 0,608 & \\
\hline \multirow[t]{4}{*}{4} & \multirow[t]{4}{*}{$\begin{array}{l}\text { Pembelajaran } \\
\text { dan } \\
\text { Pertumbuhan }\end{array}$} & $\begin{array}{l}\text { Penerapan Budaya Perusahaan yang } \\
\text { sesuai }\end{array}$ & 0,483 & 5 & 2,415 & \multirow[t]{4}{*}{4,628} \\
\hline & & $\begin{array}{l}\text { Tingkat Pemahaman terhadap Budaya } \\
\text { perusahaan }\end{array}$ & 0,141 & 5 & 0,705 & \\
\hline & & $\begin{array}{l}\text { Jumlah program pelatihan dan } \\
\text { pendidikan pegawai per tahun }\end{array}$ & 0,276 & 4 & 1,104 & \\
\hline & & $\begin{array}{l}\text { Persentase realisasi man month pelatihan } \\
\text { dan pendidikan pegawai }\end{array}$ & 0,101 & 4 & 0,404 & \\
\hline
\end{tabular}

- Pengukuran Kinerja SDM Perusahaan secara keseluruhan

Formula yang digunakan untuk menghitung nilai kinerja SDM perusahaan secara keseluruhan adalah:

\section{Nilai Kinerja SDM $=\Sigma$ (Bobot perspektif $x$ Nilai Kinerja Perspektif)}

Sedangkan formula untuk menghitung nilai kinerja SDM perusahaan ditentukan dengan klasifikasi sebagai berikut: 


\section{Nilai Kinerja Perspektif $=\boldsymbol{\Sigma}$ (Bobot tolok Ukur x Nilai Kinerja Tolok Ukur).}

Kinerja SDM Perusahaan secara keseluruhan didasarkan pada penjumlahan dari hasil perkalian nilai setiap perspektif dengan bobot setiap perspektif. Hasil pengukuran kinerja SDM PT. Asia Penta Garment adalah pada tabel berikut ini:

Tabel 5. Hasil Pengukuran Kinerja SDM PT. Asia Penta Garment Secara Keseluruhan

\begin{tabular}{|l|c|c|c|}
\hline Perspektif & Bobot Perspektif & Nilai Perspektif & Nilai Kinerja \\
\hline Keuangan & 0,439 & 3,683 & 1,617 \\
\hline Konsumen & 0,146 & 2.993 & 0,437 \\
\hline Proses Bisnis Internal & 0,311 & 3,337 & 0,996 \\
\hline $\begin{array}{l}\text { Pembelajaran dan } \\
\text { Pertumbuhan }\end{array}$ & 0,104 & 4,628 & 0,481 \\
\hline $\begin{array}{l}\text { Nilai Kinerja SDM } \\
\text { Perusahaan }\end{array}$ & & 3,531 \\
\hline Kriteria & & Cukup \\
\hline
\end{tabular}

Dari tabel di atas dapat dilihat bahwa nilai kinerja SDM perusahaan secara keseluruhan adalah cukup, dengan nilai kinerja sebesar 3,531 (terletak pada range 3,554,04, yang artinya kinerja SDM berada pada kriteria cukup). Dan pada Perspektif keuangan memberikan nilai kinerja paling besar.

\section{SIMPULAN}

Perancangan sistem manajemen kinerja SDM berbasis HR Scorecard di PT. Asia Penta Garment dapat ditarik kesimpulan sebagai berikut:

1. Cara Penilaian Kinerja SDM di PT. Asia Penta Garment dilakukan oleh atasan langsung dengan menggunakan poin-poin sebagai berikut:

a. Cara Pengambilan keputusan

b. Kreativitas dalam mencari pemecahan masalah

c. Kemandirian dalam memecahkan masalah

d. Kemampuan koordinasi dengan team

Hasil dari poin-poin tersebut akan menghasilkan penilaian A B C D, dan hasil tersebut digunakan untuk kenaikan upah karyawan.

2. Maka untuk mengidentifikasi kelemahan-kelemahan penilaian kinerja SDM yang sedang berjalan di PT. Asia Penta Garment adalah bahwa penilaian kinerja SDM masih bersifat tradisional dan hanya difokuskan pada kenaikan upah karyawan saja.

3. Penentuan variabel dan indikator untuk membuat perancangan sistem manajemen kinerja dimulai dari mengidentifikasi strategi bisnis, visi dan misi perusahaan secara jelas. Kemudian Identifikasi Leading Indicator (Faktor Penyebab) dan Lagging Indicator (Faktor Akibat) dari masing-masing perspektif Keuangan, perspektif Pelanggan/Konsumen, perspektif Proses Bisnis Internal, dan Perspektif Pembelajaran dan Pertumbuhan.

4. Perancangan Manajemen Sistem Kinerja SDM HR Scorecard melalui tahap-tahap berikut ini: 
- Melakukan Perencanaan kinerja dengan membuat peta strategi, dan Kemitraan antara HR Architecture dan HR Deliverables.

- Melakukan proses perbaikan kinerja dengan membuat tabel indikator sebab akibat dan tabel formulasi ukuran setiap indikator sebab akibat.

Dan membuat Perancangan Sistem Manajemen Kinerja SDM yaitu merancang dimensi HR Scorecard dengan penggambaran hubungan sebab akibat antar indikator dari satu perspektif ke perspektif yang lain, adalah sebagai berikut : Pada perspektif pembelajaran dan pertumbuhan, indikator jumlah program pelatihan dan pendidikan pegawai per tahun dapat mempengaruhi indikator persentase realisasi man month pelatihan dan pendidikan pegawai. Jika terjadi peningkatan pada indikator persentase realisasi man month pelatihan dan pendidikan pegawai maka akan berpengaruh pada indikator Jam pelatihan/orang/tahun pada perspektif proses bisnis internal, sehingga akan meningkatkan indikator rata-rata nilai kinerja karyawan yang ada hubungannya dengan nilai kinerja pegawai. Jika nilai kinerja pegawai tinggi maka akan berpengaruh terhadap produktivitas SDM (Rasio total pendapatan terhadap biaya SDM) pada perspektif keuangan. Produktivitas SDM juga dapat dipengaruhi oleh indikator turunnya persentase pengeluaran SDM terhadap pendapatan yang diikuti oleh menurunnya tingkat turn over pegawai dan diikuti juga oleh peningkatan kepuasan pegawai yang terdapat pada perspektif konsumen. Kepuasan pegawai akan berhasil apabila indikator dari proses bisnis internal yaitu persentase jumlah pegawai yang mengikuti pelatihan dan pendidikan terhadap total pegawai meningkat. Maka dari itu biaya program pelatihan dan pendidikan per pegawai harus selalu tersedia.

- Proses tinjauan / pemeriksaan kinerja

Proses tinjauan kinerja dilakukan dengan membuat rekapitulasi target dan pencapaian tolok ukur pada setiap perspektif, melakukan pengukuran kinerja setiap perspektif, dan nilai kinerja SDM secara keseluruhan.

Nilai kinerja SDM perusahaan secara keseluruhan adalah cukup, dengan nilai kinerja sebesar 3,655 (terletak pada range 3,55-4,04, yang artinya kinerja SDM berada pada kriteria cukup). Perspektif keuangan memberikan nilai kinerja paling besar yaitu 1,617, sedangkan pada perspektif konsumen memberikan nilai kinerja yang paling kecil yaitu 0,437 .

\section{DAFTAR PUSTAKA}

Aguinis Herman, " Performance Management", second edition, prentice hall, 2009.

Armstrong Michael, "Performance Management", key strategies and practical guidelines, kogan page, london and Philadelphia, 2006.

Armstrong Michael, "Performance Management", An evidence-based guide to delivering high performance, kogan page, Philadelphia USA, 2009.

Bacal, Robert, 2001, Performance Management. Terjemahan Suryadarma dan Yanuar Irawan, Jakarta: PT. Gramedia Pustaka Utama.

Becker, E, Brian, Huselid, Mark A, Ulrich Dave, "The HR Scorecard Lingking People, Strategy and Performance", Harvard Business School Press Boston, Massachusetts, 2001. 
Cokins Gary, "Performance Management “, Finding the missing pieces (To Close the Intelligence GAP), USA, 2004.

Dessler, Gary. (2003). Human Resource Management. Edition 9.Prentice Hall.

Fuad Anis, Nugroho Kandung Sapto, “ Penelitian Kualitatif “, Graha Ilmu, Yogyakarta, 2014

Gomez-Mejia, R. Luis, dkk (2001), Managing Human Resources, New Jersey : Prentice Hall.

John W.Baird - James B.Stull, McGraw-Hill Publishing Company American, 1986, "BUSINESS COMMUNICATION : Strategies And Solutions".

Lockett, J., (1992), Effective Performance Management: A Strategic Guide to Getting the Best from People, Kongan Page Limited, London

Mangkunegara, Anwar Prabu (2005). Manajemen Sumber Daya Manusia SDM

Perusahaan, Bandung, PT. Remaja Rosdakarya.

Mintzberg, H., J.B. Quinn and J. Voyer, 1995, “The Strategy Process “, New York: Prentice-Hall, Englewood Clifffs.

Mitrani Alain, et al. (1992). Manajemen Sumber Daya Manusia berdasarkan Kompetensi. (Dadi Pakar: Penerjemah). Jakarta(Pustaka Utama Grafitri).

Mohrman, AM. \&Mohrman, S.A. (1995). Performance management is ,running the business". Compensation and Benefits Review, July-August, pp. 69-75.

Rivai Veithzal, Sagala Ella Jauvani, “ Manajemen Sumber Daya Manusia untuk Perusahaan", edisi kedua, PT. Rajagrafindo Persada, Jakarta, 2009

R. Jauch, Lawrence, and F. Glueck, William. Manajemen Strategi dan Kebijakan Perusahaan, Jakarta : Edisi ketiga, Erlangga 1997.

Scher erhorn, 2002, management, $7^{\text {th }}$ ed., New York : John Wiley \& Sons Inc.

Thomson, A., A., dan Strickland A.J. (2001). Strategic Management, Concept and Cases, $12^{\text {th }}$ Edition, Mc Graw-Hill, Singapore.

Tunggal, Amin Widjaja, Drs, Ak. MBA, (1994), Manajemen Strategik Suatu Pengantar, Harvarindo, Jakarta. 
Yuliati, Dini. 2019. Perancangan Sistem Manajemen Kinerja SDM Berbasis

Human Resources Score Card di PT Asia Penta Garment. Sainteks, 1(1): 1-16. 